\title{
The Anatomy of a Misfit: The 2014 European Election in Malta
}

\section{Marcello Carammia and Roderick Pace}

The 2014 European election in Malta did not put the party system under stress, and in many ways resembled past elections. The two parties that have dominated Maltese politics since independence shared the seats equally between them. Once again, the 'third', green party failed to obtain parliamentary representation, as did the far-right party despite doubling its votes. The good fit with the second-order election model marked Malta as Southern Europe's misfit. While the comparatively weak impact of the economic crisis was a contributory factor, a combination of institutional, cultural-historical and contextual factors provide a more accurate explanation. Political institutions are particularly relevant because they reinforce the perfect two-party system - the key to Malta's political stability - and shield it from the challenge of outsiders.

Keywords: European Parliament Elections; Malta; Second-Order Election Model; Party System; Single Transferable Vote; Bipolarisation

The third European Parliament election since Malta joined the European Union (EU) took place on 24 May 2014. The two main political parties - the governing Labour Party (Partit Laburista; PL) and the opposition Nationalist Party (Partit Nazzjonalista; $\mathrm{PN}$ ) - together took 93.4 per cent of the valid votes cast. Less than five per cent of the electorate decided to switch its vote from the big parties to the smaller, 'fringe' parties - not enough to cause a sensation. This confirmed that the party system remains stable and extremely resistant to change, given that Labour and the Nationalists have dominated it for the past 48 years.

Compared with other southern EU member states, the outcome of the 2014 European election makes Malta look like a deviant case. There was no shake-up of the party system and nor did any Eurosceptic party seriously threaten political stability in the country. The six seats contested were equally divided between the two main parties. The quota for electing one member of the European Parliament (MEP) was just under 36,000 votes, a threshold too high for any of the small parties to overcome failing a seismic electoral shift. 
Once again, the third party, the green AD (Alternattiva Demokratika; Democratic Alternative) failed to secure parliamentary representation. The Eurosceptic and farright party Imperium Europa (IE) almost doubled its vote tally over the 2009 European election, but this was not enough to allow it to capture a seat in the Parliament. The EU was a relatively uncontroversial issue in the campaign. In sum, the election showed signs that it conformed to the second-order election (SOE) model (Reif \& Schmitt 1980), where voters perceive little is at stake and vote on the basis of domestic rather than EU-related concerns.

Why did the European election largely conform to the SOE model? Was Malta really left untouched by the Eurosceptic wave that shook Southern Europe? How can the outcome of the election in Malta be explained? An intuitive response might be that the country had been only marginally affected by the economic and financial crisis that hit the rest of Europe. Yet this would only be a partial explanation for, as we will show, the Eurosceptic tide did not leave Malta entirely untouched. Malta's relatively quiet European election, we argue, is more accurately explained by a combination of domestic institutional, cultural-historical and contextual factors.

Political institutions, notably the two-party system and the strongly majoritarian institutional design, give the system a remarkable stability and shield it from being challenged by outsiders. In a context in which elections are won by very narrow margins, a highly polarised political culture supports and effectively reinforces partisanship. This happens despite Malta's proportional electoral system based on the single transferable vote (STV).

Against this background, the country's recent history has also contributed to the marginalisation of anti-EU forces. Membership was long a contested issue in Malta. Between 1990 and 2004 it was one of the main cleavages between the pro-European Nationalists and anti-European Labour. When the 2003 membership referendum and the national elections that followed resulted in a victory for 'yes' and for the PN that supported it, Labour overhauled its EU policy. Given that AD is strongly proEuropean, one may infer that Euroscepticism is practically absent from Malta's party system - although not completely, as we shall show below.

The more recent context also provided little incentives for political actors to campaign against the EU. Ten years after accession, the benefits of membership are still clearly felt from a period of sustained economic growth. Overall, the costs of adapting to Europe were outweighed by the benefits, and this was made very apparent to the public by the effective use of cohesion funds. Moreover, the economic transformation was paralleled by a societal change that shifted significant sectors of the population towards more post-materialist attitudes, as epitomised by the introduction of divorce after the 2011 referendum and a law on same-sex marriage in 2014.

The article proceeds as follows. Below we outline the SOE model and its related expectations. We then move to the three central factors of our explanation for the election result, which are discussed in separate sections: institutional, culturalhistorical and contingent factors. When discussing short-term contingent factors, we also illustrate the background to the European election and the election campaign. 
We then analyse the election results in the light of the SOE model to see whether and to what extent they conformed to the related expectations. The conclusions reappraise the findings and discuss their significance.

\section{The Second-Order Election Model}

Advanced for the analysis of the first round of European elections in 1979, the SOE model is based on the assumption that voters believe little is at stake in European elections (Reif \& Schmitt 1980, p. 9). This informs voting behaviour and makes European election results systematically different from national, first-order elections (FOEs). The SOE model presents two sets of aggregate hypotheses. ${ }^{1}$ The first set concerns electoral participation: since the low stakes provide a weak incentive for voters to go to the polls, turnout at SOEs will be lower than in FOEs; for the same reasons, a higher percentage of invalid votes will be recorded.

A second set of hypotheses concern party choice and electoral outcomes. First, voters use SOEs as a referendum to sanction or reward parties in government. This generally results in governing parties losing votes to opposition parties - with an important qualification. Whether and to what extent governmental parties actually lose votes depends on when the SOE takes place within the electoral cycle: that is, how close an SOE is from the previous and next FOEs. When an SOE takes place shortly after a national election, government parties will be protected by the 'honeymoon effect'. The remaining party choice hypotheses of the SOE model posit that, since voters understand they are not electing a government, they are less likely to vote strategically and more inclined to vote for the party closest to their policy preferences. In terms of electoral outcome the prediction is that, in comparison with FOEs, big parties lose and small parties gain votes.

When applied to Malta's 2014 European election, the electoral participation hypotheses would thus predict a lower turnout and higher percentage of invalid votes. The expectations related to party choice hypotheses are less straightforward. In principle, the honeymoon effect is expected to last 12 months. ${ }^{2}$ However, the European election fell only 15 months after a national election won by Labour after nearly 25 years in opposition. Hence, we could expect the honeymoon with voters was not entirely over, which implies that the prediction that the governing party ought to lose votes should be tempered. Finally, the SOE model predicts big parties will lose and small parties will win. While we expect this prediction to apply, we also argue that Malta's political institutions significantly limit the magnitude of the effect. Therefore, we expect significant but not massive losses for the big parties, and significant but not massive gains for the small parties.

The SOE model has been tested in successive European elections (Carrubba \& Timpone 2005; Schmitt 2005; Koepke \& Ringe 2006; Hix \& Marsh 2007; 2011; Marsh 1998; Hobolt \& Wittrock 2011). The model encountered strikingly strong and consistent empirical support. However, some studies noted some mechanisms that under different circumstances may lead to different voting results. Thus, Hobolt and 
Wittrock (2011) found that more information about party stances on European integration may weaken the SOE effect, while Hix and Marsh (2011, p. 13) noted 'the emergence of one aspect of a pan-European public opinion'. Together, these findings indicate that were the context to change, voting behaviour in European elections might also be affected.

In this respect, the 2014 European elections provided a stern test for the SOE model, particularly in Southern Europe. Five years of economic crisis and austerity policies made the EU both more salient and less popular among electorates. EU institutions have largely been blamed for late and ineffective decisions. Those who blamed the EU - or, in some variants, the euro - as the main cause of the crisis and the failure of the recovery gained centrality in media and political debates. In sum, in many countries particularly in the south - the context of the 2014 European election was more in line with a 'Europe matters' than with a 'less at stake' view. As we show below, Malta's European election largely conformed to the SOE model, and that is only partially explained by the softer impact of the economic and financial crisis on the island. A thorough explanation, we argue, needs to take into account Malta's political institutions and the long- and short-term context of the election.

\section{The Political Institutions of Malta: Bipolarisation, Stability and Majoritarian Democracy}

Malta is a textbook case of a majoritarian democracy (Lijphart 1999). It is a perfect two-party system, in which only the two main parties, the Nationalists and Labour, gain access to parliament. Between 1966 and 2013, the effective number of parties (ENP) (Laakso \& Taagepera 1979) ranged between 1.97 and 2 (with an average of 1.99) in terms of parliamentary seats, and between 2 and 2.39 (with an average of 2.07) in terms of votes. Third parties have found it impossible to upset the Labour-Nationalist duopoly, notwithstanding the STV proportional representation (PR) system (Katz 1984). Malta's two-party system seems to confound Duverger's Law (Pace 2005, p. 124), which posits that PR systems should be conducive to multi-party systems (Duverger 1951). The small number of parties, however, is explained by the small size of the country (Sikk \& Taagepera 2014) with its population of 425,385 (Eurostat 2015), its (extremely low) social heterogeneity (Taagepera 1999) and the historical context of the transition to independence (Cini 2002).

The major institutional factor affecting Malta's party system is the electoral system. Parties are listed on the ballot in alphabetical order and candidates are also listed in alphabetical order under each party heading. Voters mark their preferences in a slot next to the candidate's name and party symbol. They can also vote across party lines. A Droop quota is used to establish the number of votes candidates must poll to secure a seat. ${ }^{3}$ Candidates with the lowest number of votes being eliminated from the contest, their votes are redistributed among the remaining candidates according to voters' preferences. When a candidate reaches the quota, he or she is declared to have been elected, the process continuing until every seat is filled. At times, as happened in the 
2014 European election, the last seat may be filled without a quota: when the last two remaining candidates do not have sufficient votes to achieve it, the seat goes to the candidate with the greatest number of votes.

In national elections, Malta and the smaller island of Gozo are divided into 13 electoral districts, each returning five members of parliament (MPs). Although the electoral law ensures proportionality between the preference votes obtained nationally by the parties and the parliamentary seats allocated to them, this mechanism operates only if a party manages to elect at least one MP and no more than two parties enter parliament. For the allocation of seats, candidates, votes and voters are kept separate in each district, which turns the general election into 13 separate ballots occurring simultaneously. Therefore, for a party to elect a seat, it needs to obtain 16-17 per cent of the vote in an electoral district. This threshold is very high and difficult for new and small political parties to achieve. ${ }^{4}$ In the European elections the Maltese islands become a single electoral district, thus the threshold is even higher. The quota has ranged from 40,954 in 2004 to 35,979 in 2014, a nationwide threshold of, respectively, 17 and 14 per cent, which is very difficult for small parties to attain. Only AD in 2004, with a first-count tally of 22,938, managed to cross half the distance to the quota. This mechanical effect of the electoral system is obviously strengthened by a psychological effect, which reinforces the strategic vote for bigger parties (Duverger 1951).

The second factor that accounts for the party system's stability is historically rooted. From the end of the Second World War to 1966, although Labour and the Nationalists had already emerged as the leading parties, there were a number of smaller parties in parliament, most of them splinter groups from the two main parties. This led to a series of unstable coalition governments between 1950 and 1955. In 1955, Labour won an overall majority, then in 1962 the same feat was repeated by the Nationalists after securing a single-seat parliamentary majority when a member of the smaller Democratic Nationalist Party defected and joined it. From then onwards the electorate consolidated around the two main parties: in less than a decade, all trace of the smaller parties had disappeared as their supporters, activists and voters shifted their allegiance to the two larger parties. This electoral alignment was reinforced by socio-cultural factors (Cini 2002), given Malta's largely homogeneous society in terms of (Maltese) language and (Catholic) religion. Furthermore, the two large parties have consolidated their party organisations throughout the national territory with their own clubs in every locality, radio and television networks, newspapers and social media. This makes it difficult for any small political formation lacking similar resources to match them in electoral campaigning.

The electoral system and the historic developments leading to the disappearance of the small parties, together with the consolidation of the power bases of the two large parties, have cast the political system into a Labour-Nationalist duopoly that has proved difficult to change. The political system cloned from the Westminster model concentrates power in the hands of the prime minister, and strengthens the adversarial nature of Maltese politics. The upside of this system is that it provides stable governments that normally last the full term. The downside is that it strengthens 
political division in such a small society as Malta's. The country's majoritarian model under STV means election winners gain full control of the country's political institutions and civil service. Since elections are often won by narrow margins, ${ }^{5}$ voters have a powerful incentive to go to the polls. This explains Malta's (declining yet still) near-universal turnout (Hirczy 1995), which at national elections is generally around 95 per cent, despite the fact that voting is not compulsory.

In sum, political institutions provide the system with a remarkable stability (Pace \& Carammia forthcoming). The electoral system in particular supports an exceptionally high threshold that prevents the entry of outsider parties that could challenge the Labour-Nationalist hegemony.

\section{The Long-Term Background: Malta-EU Relations Before the 2004 Enlargement}

The history of Malta's relations with the EU and application for membership is one of ups and downs, mostly coinciding with the terms in government of the Nationalists and Labour (Cini 2000; 2003; 2004; Pace 2002; 2004; 2005), but also crossing the deeper, multiple European/Mediterranean identities of the Maltese. After being elected to govern the country before and immediately after independence in 1964, the Nationalist Party pursued close relations with the EU. Labour won the national elections in 1971, opening a long cycle of Labour government lasting until 1987. The policy of close cooperation with the EU was not substantially changed despite the shift towards non-alignment and Third-World socialism under Dom Mintoff's charismatic leadership.

The EU really became a hot issue after the return to government of the Nationalists in 1987 and the 1990 membership application. So much so that for some years this acute bipolarisation on EU membership even defined the main cleavage in Maltese politics (Cini 2000; Pace 2002, p. 32). Initially, Labour oscillated between an unclear pragmatism and a clear opposition to membership. Eventually, the latter became the official position, and when Labour won the 1996 election the application was suspended.

The 1996 Labour government was short-lived, and when the Nationalists returned to government in 1998 they revived the application and obtained membership (Pace 2004). EU accession was put to a popular referendum, following which a national election was also called. Thus, in 2003 Malta voted twice for Europe (Cini 2003). The 'yes' front won the referendum by a margin of 52.9 to 42.7 per cent, and the Nationalists won the national elections.

The political confrontation surrounding membership left a deep mark on Malta's politics. The Nationalists received a boost, which retrospectively makes the 1996-98 Labour government a short parenthesis within a long Nationalist cycle lasting about 25 years. Labour won the 2004 European election, but narrowly lost the 2008 national elections and was compelled to elect a new leader. With its new leader and party structure, Labour increased its margin over the Nationalists in the 2009 European election and, most importantly, won the 2013 national elections by a landslide. 
Malta's European and Mediterranean identities (Cini 2000) could finally coexist peacefully (Cini 2004; Pace 2005). The obvious political consequence of the path to membership was that incentives for any of the main parties to campaign against the EU were, at least for some time, removed from the system. Moreover, in just a few years, EU membership managed to acquire a positive image among a large section of the population. This and other shorter-term contextual factors are discussed below in the analysis of the election campaign.

\section{Ten Years of Membership and the Context of the Elections}

The first decade of membership resulted in the transformation of Malta's society. The economy adapted relatively quickly, while sustained economic growth eclipsed the austerity policies pursued during the negotiations and the first years of membership to put the country's economy and finances on a sustainable path. The whole decade passed under Nationalist governments. Labour came close to victory in the 2008 national elections, but the Nationalists were eventually confirmed winners (Fenech 2008). The Nationalists successfully pursued liberal economic policies. Their work was facilitated by the emergence of a substantial economic consensus between the main parties: electoral competition shifted away from policy agendas towards issues of competence and approach to problems (Fenech 2013).

In the last term (2008-13) of almost a quarter of a century of Nationalist government, the public mood began to lean towards change. The Nationalists had clearly run the economy well, but were facing discontent and criticism of nepotism and corruption. The first two European elections, held in 2004 and 2009, were won by Labour, which was effectively renewing its policy and leadership (Pace 2005, 2009, 2011). The policies and strategies of the two main parties diverged most in the sphere of values. The debate heated up and became very contentious during the 2011 referendum on divorce. A revival of conservative religious influence within the Nationalist Party had become increasingly evident in the last six years, and the party took a strong position against divorce. Conversely, Labour, which had a long history of laity and even overt confrontation with the Catholic Church, took a clear position in favour of divorce (Pace 2012). The 'yes' front eventually won by an unexpectedly comfortable margin, which left the Nationalists as a party 'divorced from reality' (Fenech 2012). Laity became a hallmark of the renewed Labour Party, which once back in government immediately passed a law on same-sex marriage.

A core element of the change in the public mood of the post-membership decade was the attitude towards the EU. This is shown in Figure 1, which presents Eurobarometer data on the image of Europe among the Maltese public in the period 2003-13. The figure shows data about Malta, as well as the EU average, other southern member state averages (Italy, Spain, Greece, Portugal and Cyprus) and the average of 2004-07 accession states (excluding Malta). The trend line indicates the net image of Europe, which we created by subtracting negative from positive "images of Europe". In 2004, this indicator was relatively low for Malta (27 per cent) in comparison with 
the EU average (38 per cent), the average for new member states ( 40 per cent) and especially the significantly higher net positive image the EU enjoyed in Southern European member states (48 per cent). This is scarcely surprising, as the data were collected only a year after the divisive EU referendum. Things could not have been more different in 2013, at the end of the series. In the rest of Southern Europe, negative images surpassed positive ones by 21 points. In the EU as a whole, there was basically no gap, with positive and negative views balancing out each other. The EU enjoyed a better image among citizens of new member states, with a positive gap of 13 points. In comparison with all other areas, the 27 per cent positive gap observed in 2013 in Malta was impressive.

The disaggregated data show that over time the share of Maltese public opinion with a positive image of Europe averaged around 45 per cent, with a slightly upward trend after accession and a slightly downward trend from 2009 to 2011, during the first part of the international financial crisis. Similarly, the share of the population with a negative image of Europe has been relatively low and overall constant, except for a moderate increase in 2009-11. The group that is perhaps most similar to Malta is that of the new member states, the citizens of which still have relatively pro-EU views. Most importantly, the share of Malta's population with a positive image of the EU is far higher than the average in other Southern European countries. Even more marked is the gap between positive and negative perceptions, strikingly lower in Malta than in the other southern EU countries. While at the beginning of the series, in 2004, positive attitudes towards the EU were lower in Malta than in any other group, by 2013 they were consistently higher than in all of them. Meanwhile, the share of Malta's population with a neutral image of Europe has been on the increase, which indicates Malta still has a permissive consensus towards the EU (Lindberg \& Scheingold 1970).

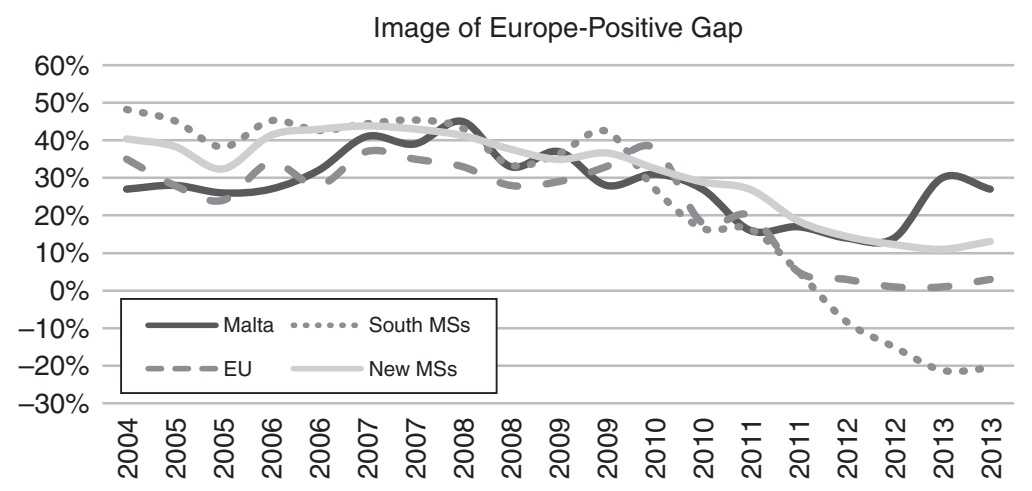

Figure 1 Public Opinion of Europe - Malta, EU, Southern Member States and New Member States Compared (2004-13)

Source: Authors' elaboration on Eurobarometer data, available online at: http://ec.europa. eu/public_opinion/index_en.htm. Answers to the question: 'In general, does the European Union conjure up for you a very positive, fairly positive, neutral, fairly negative or very negative image?' 
Figure 1 shows that the difference between Malta and other southern member states (but also, though to a lesser extent, between the new member states and the EU average) became noticeable around 2010-11, and then widened greatly. The negative turn within southern public opinion coincided with the economic crisis, financial turmoil, austerity policies and the generalised shift of blame towards the EU. In this respect, Malta looks like an entirely different case. One reason behind the peculiar nature of the Maltese 2014 European election when compared with most of the other Southern European countries is that the Maltese economy has been left largely unscathed by the financial crisis and the economic downturn. The crisis did slow down the Maltese economy, yet economic growth turned negative only for a few months in 2009 and regained a sustained pace in 2012 and 2013. Unemployment remained relatively low - strikingly so in comparison with other southern member states - at around 6.5 per cent, and the expectations were of strong economic growth in the next few years.

Against this changing context of Maltese society, the 2013 national elections eventually brought the long-awaited shift in the electorate (Fenech 2008, 2013). After having failed by a small margin in 2008, the renewed Labour Party won by a landslide, with an impressive margin of 11.5 points over the Nationalists. The government was still in its honeymoon period when the campaign for the European election began.

\section{The Election Campaign}

Preparations for the European election started soon after the March 2013 national elections. In July, the Labour Party opened nominations for potential candidates while the Nationalist Party's executive council approved eight candidates. Labour approved its first batch of candidates in August, then AD announced its two candidates in December. The campaign slowed down over Christmas and New Year, but picked up again soon after the festivities, the Nationalists announcing their second batch of candidates in January 2014.

Probably the most controversial - and, with the benefit of hindsight, significant choice by the Labour Party was to nominate former party leader Alfred Sant as a candidate. Dr Sant was the leader of the party when it won the 1996 national election, but also when it lost those of 1998, 2003 and 2008. He had actively campaigned against Malta's EU membership, and doggedly refused to recognise the result of the 2003 membership referendum. Notwithstanding the fact that some Labour supporters were critical of his stance on Europe, he still enjoyed overwhelming popularity among them. Pre-election opinion polls constantly showed he was likely to be elected first from among his fellow party candidates, if not from among all candidates. The election confirmed this prediction, for he polled enough votes to be the only candidate to be elected on the first count, with a few thousand votes to spare. This certainly influenced Labour's post-election decision to ask him to lead its European delegation.

In November 2013, the Nationalist Party mounted a concerted campaign, both in Malta and in the European Parliament, against an investment scheme launched by the 
government consisting of the issuing of Maltese citizenship to foreigners investing in Malta. The debate peaked on 16 January 2014 when the European Parliament approved a resolution on the sale of EU citizenship. The scheme had to be amended several times to make it conform to EU requirements, and the controversy raged right up to the European election. The beginning of this issue served as an avant-propos of the main European campaign - the pace of which really started picking up in April 2014.

On 21 April, the two main political parties held rallies to mark the start of their campaigns. Labour's slogan was 'Positive Energy', while the Nationalists chose 'A Better Malta'. The Nationalists appealed to voters to use their votes to show their disappointment with the way the Prime Minister was running the country, claiming that pre-election Labour promises of meritocracy, transparency and 'a government that listens' had all been set aside by the new government. Labour responded with claims it was keeping its election promises. The centrepiece of its campaign was the reduction of energy prices for households, announced in the 2014 budget that had been approved on 21 November 2013. These reductions were timed to take effect in March 2014, just before the start of the last phase of the European election campaign. Energy prices for households were one of the main issues on which Labour had won the 2013 national election.

\section{Absence of Europe}

The main political parties issued electoral manifestos based on their respective political groups' programmes. Concurrently, individual candidates organised their own personal campaigns. In May the broadcasting authority started a series of debates, while the main parties put up billboards around the islands and employed their media (newspapers, television and radio channels, social media, etc.) to the full. The campaign had a strong second-order imprint from the very beginning. It was soon dominated by domestic political issues largely mirroring the main concerns of public opinion, European ones being sidelined. Prominent issues included a planned new electricity-generating plant in the south of the island, the resignation of a minister and a junior minister which precipitated a cabinet reshuffle, the election of a new president of the Republic and the Civil Union Act (Harwood 2015). Approved on 14 April 2014, the Act once again split the Nationalist Party to the point that it had to abstain in the parliamentary vote - a not very auspicious start to its European campaign.

Limited space was given to the discussion of deeper EU issues. The only moments when more space was afforded to them was when Martin Schultz and Jean Claude Junker addressed meetings during their visits to Malta to campaign as the presidential candidates of their respective political groups. From this angle, the idea to tie the appointment of the president of the Commission to the outcome of the European elections benefited the mobilisation of Maltese public opinion on EU issues, although the significance of this in comparison with the rest of the campaign was rather circumscribed. Even when the media presented the political messages of Schultz and 
Junker, they tended to give them a local bias to make them appeal more to their respective local followers.

The leaders of both Labour and the Nationalists emphasised their personal acquaintance with the respective political group's presidential candidate, to signal to voters that a vote for them was a vote for a party that would have influence in a future Commission. Both Schulz and Juncker emphasised the need for an EU approach on immigration; not coincidentally, as this is an issue of recurrent concern for the Maltese. Juncker pledged that should he became Commission president he would ensure that EU solidarity on migration would not remain an empty promise.

For its part, $\mathrm{AD}$ adopted positions on the main issues discussed by the two main parties, among which immigration featured prominently. AD stressed the need for responsibility sharing and a European policy on legal migration. It also emphasised its European credentials, stressing that together with the European Greens, of which it is a member, it could contribute to improving the quality of life of the Maltese, particularly in terms of social and environmental standards. AD has been a vociferous opponent of spring hunting, supported in turn by a strong lobby. AD's campaign led to the establishment of a coalition of non-governmental organisations that collected more than 43,376 signatures to force an abrogative referendum to ban the practice. Other issues championed by AD included food safety, clean air and renewable energy; an EU that works for peace, human rights and international cooperation; and the protection of citizens' digital rights and personal data.

The voice of the far right, IE, like that of all the other small parties, was less audible. Its campaign was largely confined to social media; it obtained limited access to the state media when it participated in debating programmes organised by the broadcasting authority. In its manifesto, IE expressed itself as against a mercantile Europe and in favour of a new Europe of regions and peoples. It emphasised its belief in high culture and the separation of Church and state. It claimed Europe is capable of feeding itself and of sustaining its ageing population without the need for immigrants. The party called for tax incentives to encourage young couples to have more children, the protection of the environment, an end to immigration and the preservation of Europe's racial and cultural identity.

The election campaign was largely inward-looking. The campaigns of the main parties were much scaled down in comparison with national election campaigns. Notwithstanding the growing significance of the EU, the increasing power of the European Parliament and even the relevance of the 2014 election to the appointment of the Commission president, the focus on national issues ensured voters did not debate the importance of the European Parliament. Domestic issues, such as the construction of a new power plant, were far more central than such broader EU issues as the austerity-growth debate or the fate of the European currency. Occasionally, the EU did enter the discussion, but there was no grand debate on big EU choices: Europe featured only when connected to domestic issues. This was also true of the visit by the candidates for the presidency of the Commission: in their public appearance, they discussed those issues of concern to the domestic population 
where the EU could have a role, such as migration and energy. Overall, the shortterm context of the election and the election campaign was largely in line with SOEs where little is at stake (Reif \& Schmitt 1980) and the EU does not matter (Hix \& Marsh 2007). The extent to which election results also conformed to the SOE model is discussed below.

\section{The Vote and the Election Results}

We have so far shown how political institutions reinforce Malta's political stability, and how historical factors and the context of the election contributed to depoliticising EU issues. Such a depoliticised context is a key prerequisite of the SOE model, which, we argue, explains much of the election results. We now move on to illustrate the results of the election, and its consistency with the SOE model. The lack of individual-level data prevents us from conducting a systematic test of the hypotheses; however, we seek to make the most of the available aggregate data by providing a number of indicators and discussing the extent to which they conform to, or depart from, the expectations of the SOE model.

Newspapers covered the election campaign with a number of pre-election surveys of the party strengths. The newspaper that surveyed voters most consistently was MaltaToday (Debono 2014). Table 1 shows the results of monthly averages in March and April, and of the last survey carried out on 22 May, just two days before the election. These polls showed the Nationalists continuously trailing Labour by a substantial margin. The polls predicted the result fairly accurately, although they underestimated the scale of Labour's victory. ${ }^{6}$ The results of the 22 May survey are particularly interesting because, absent official individual-level data on the election at the time of writing, this was the only evidence available of where voters came from in terms of voting in the previous FOE.

Table 1 Voting Intentions in Maltese Pre-election Polls 2014 (\%)

\begin{tabular}{|c|c|c|c|c|c|c|}
\hline \multirow{2}{*}{$\begin{array}{l}\text { Party that } \\
\text { respondents are } \\
\text { intending to } \\
\text { vote for }\end{array}$} & \multicolumn{3}{|c|}{ All respondents } & \multicolumn{3}{|c|}{$\begin{array}{l}\text { Party that respondents in the } 2013 \text { national } \\
\text { election voted for }\end{array}$} \\
\hline & March & April & 22 May & Nationalist & Labour & $\begin{array}{l}\text { Vote switchers: } \\
\text { Nationalist in } 2008 \\
\text { to Labour in } 2013\end{array}$ \\
\hline Nationalist & 25.5 & 31.7 & 31.5 & 86.1 & 1.2 & 10 \\
\hline Labour & 32.7 & 35.3 & 37.2 & 1.4 & 80.8 & 30 \\
\hline $\mathrm{AD}$ & 1.3 & 1.8 & 2.9 & 1.4 & 0.8 & 10 \\
\hline Others & 0.5 & 0 & 1.2 & 0.5 & 0.8 & 0 \\
\hline Don't know & 25.5 & 17.0 & 11.5 & 6.2 & 7.7 & 40 \\
\hline Not voting & 5.3 & 5.2 & 5.4 & 0.9 & 5.7 & 10 \\
\hline No reply & 9.2 & 9.0 & 10.3 & 3.5 & 3.0 & 0 \\
\hline
\end{tabular}

Source: Own elaboration from data published by MaltaToday, available online at: http://www. maltatoday.com.mt/news/europe_2014/39279/maltatoday_survey_labour_in_sixpoint_lead\#, VHCMk_15OVV 
The large majority of those who voted for the main parties in the 2013 national election were willing to confirm their preference. More than ten per cent were undecided, and only about four per cent declared they would vote for smaller parties a small fraction, though not so small according to Maltese standards. MaltaToday also asked respondents to indicate whether they had switched their vote between the 2008 and 2013 national elections. In this way, the voting intentions of the very important swing voters could be measured. Two days before the election, 40 per cent of vote switchers remained undecided and ten per cent were unwilling to go to the polls. About one-third declared they were inclined to confirm their preference for the governing Labour Party, while 20 per cent were equally divided between the main opposition party, the Nationalists and the AD. Eventually, however, most voters voted for the two main parties. This is consistent with the argument made above about the psychological effect of the electoral system, which discourages sincere voting - even in European elections.

Table 2 includes data on the three rounds of European elections held in Malta, the preceding national (first-order) elections and the difference between them. About 258,000 voters -74.8 per cent of those entitled to vote - went to the polls. This would be a very high participation rate elsewhere in Europe, but was less so in Malta. Turnout was four points lower than in the previous European election, while in comparison with the 2013 national elections it was about 18 points lower. The percentage of invalid votes cast was 2.2 per cent, slightly higher than the 1.4 per cent registered in the 2013 national election.

While Malta's electoral system may not be one of the most complex in the world (Hirczy 1995), it is certainly a complicated one: in fact, counting was not completed until the evening of 28 May - a whole four days after the polls closed. Once again, in the European election voters rewarded Labour - at least in terms of votes. However, whereas in the 2004 and 2009 elections it was in opposition to the Nationalist government, in 2014 Labour was running as the incumbent. The 54.3 per cent of first preferences received, largely similar to the result of the 2013 national elections, confirmed the government was still in its honeymoon period with the electorate. The Nationalists, in turn, replicated their 2009 performance - when they were in government. The party received 40 per cent of first preferences, winning three instead of two seats. In comparison with the 2013 national elections, the gap between the two main parties widened by two per cent points in favour of the governing party.

Taken together, the two main parties received a respectable 93.4 per cent of votes and all of the seats. The most distinctive feature of Malta's party system - its two-party character - was not affected by the winds of European contestation. However, while in the 2013 national elections the two main parties left only 1.8 per cent of the vote to the other parties (almost all of which went to AD), the 6.5 per cent of the votes that went to the other parties at this European election held some surprises. AD continued their slow - and to many hopeless - march towards parliamentary representation, gaining almost one point over their result at the 2013 national elections, but only a half-point on their 2009 European election result. 


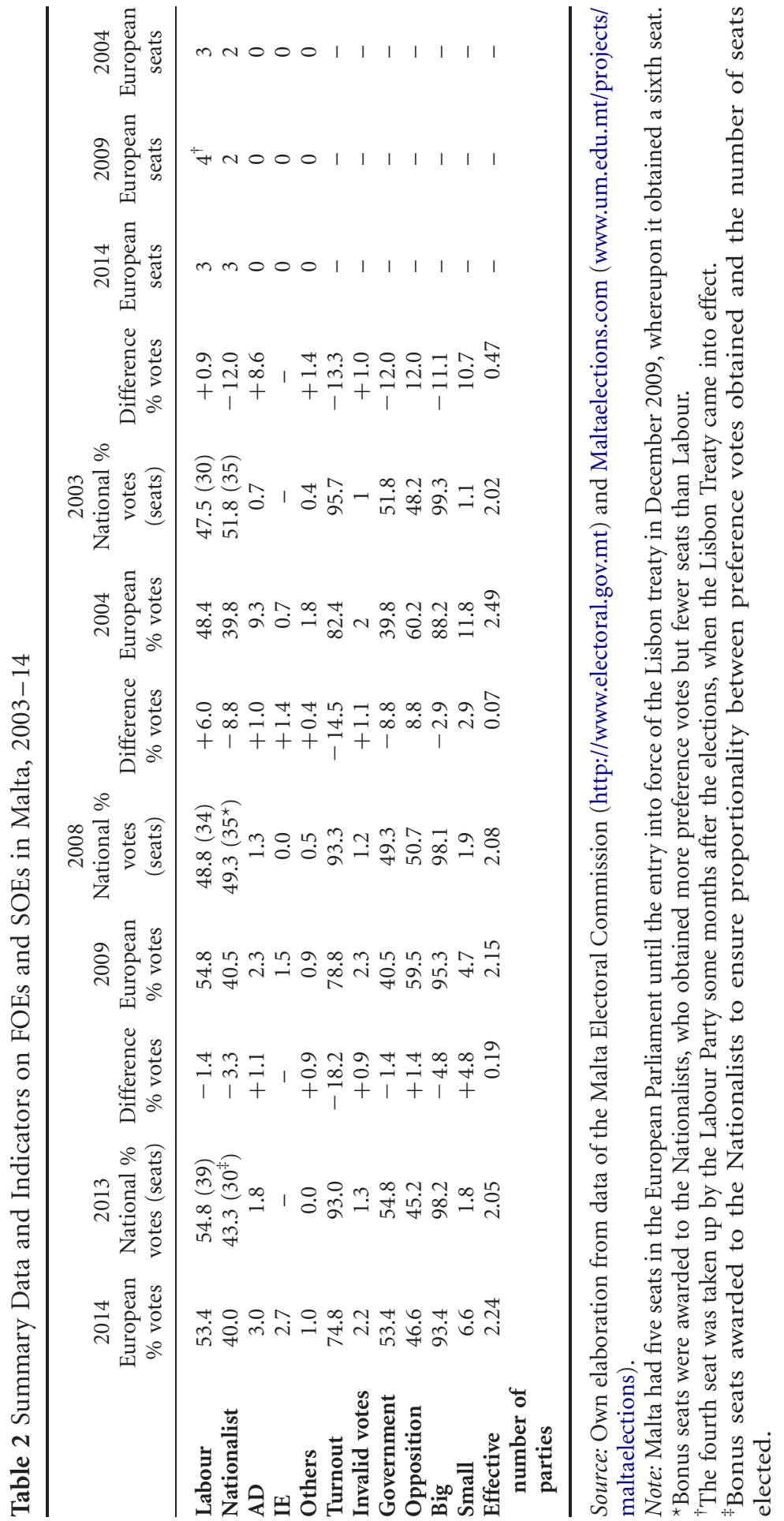


One surprise came from the number of women elected. Although the STV is generally considered to penalise them (Lane 1995; Ortega Villodres 2008), this time the Maltese elected more women (four) than they did men (two). Malta had not elected women to the European Parliament until a year before, when three women replaced the MEPs who resigned after being elected to the national parliament. The prevalence of women MEPs could be one more sign of the broader societal change of recent years, culminating in the 2011 divorce referendum and the 2013 Civil Unions bill. The most surprising - though admittedly largely unnoticed - result, however, was the growth of the neo-fascist IE, which jumped to 2.7 per cent. Not only did it almost double the number of votes it had won at the 2009 European elections, it also came close to threatening AD's position as Malta's third party.

Overall, the vote consolidated the shift of the Maltese electorate towards Labour, which tightened its hold on the country. The defeat of the Nationalists was obscured by the intricacies of the STV system, which turned a defeat in terms of votes into a 3-3 draw in terms of seats. Ironically, having managed to win three seats for the first time, the Nationalists could even claim their own victory: this time the losers benefited from the disproportional effects of the system and its occasionally perverse consequences (Doron \& Kronick 1977). These can be more marked in European elections because the number of parliamentary seats is fixed at six and cannot be increased to ensure proportionality between seats and votes as happens in national elections.

\section{A Second-Order Election?}

Table 2 includes further indicators relevant to the SOE model for all European elections and the domestic elections held before them. All the indicators support the SOE model: turnout and valid votes are systematically lower than in previous FOEs; parties in government lose and parties in opposition gain votes; smaller parties do better; larger parties do worse. That was also true of the 2014 election, which, however, when compared with previous European elections, appeared a somewhat less marked case of SOE.

Turnout declined by 13 points in 2004 compared with the 2003 national elections, and kept falling in the 2009 and 2014 European Parliament elections. In the 2004 election, large parties lost about 11 points to small parties relative to the national elections held in 2003. Almost all those votes were lost by the Nationalists in government and gained by small parties, particularly $\mathrm{AD}$, which never managed to come close to that result in subsequent elections. This result may have left an important mark on the electorate, as its memory may still discourage voters from supporting small parties for fear of wasting their votes. In 2009, large parties only lost three points to small parties. The Nationalists, then still in government, lost nine points to opposition parties, but the votes shifted to Labour rather than to the smaller parties.

In the 2014 election, the party in government - this time Labour - did only slightly worse than in the 2013 national election. It lost 3.3 per cent points, but it still obtained 
more than 50 per cent of valid votes and emerged as the indisputably strongest electoral force. The relative success of Labour in government differed from the pattern of earlier European elections, and was also a partial deviation from the SOE model. True, the SOE model expects government parties to perform better when they are close to the beginning of the electoral cycle (that is, when an SOE is held not long after an FOE). It still remains to be explained, however, why parties in government did much worse in past European elections $(-12$ and -8.8$)$ even though SOEs were held virtually at the same distance in time from the preceding FOE.

A possible explanation could be that the previous European elections fell within a longer electoral cycle, one that had begun when the Nationalists first entered in government in 1987 and lasted (with a short interruption in 1996-98) until Labour's victory in 2013. Therefore, when the 2004 and 2009 European elections were held the Nationalists were not (only) at the beginning of 'new' electoral cycles that began with the national elections of 2003 and 2008, respectively, but were also approaching the end of the longer cycle that had begun in 1987. In contrast, the 2014 European election fell close to the beginning of an entirely new Labour Party cycle, thus the party in government could actually benefit from the proximity of the two elections: Labour had just emerged from a large national election victory in March 2013, one with few precedents in Malta's electoral history, and the majority of voters still supported it.

Lacking individual-level data, we cannot offer systematic evidence for this explanation. However, the aggregate data seem to support it. It is also confirmed by pre-election surveys of swing voters (Table 1), which showed how a large share of those who had voted for Labour in the 2013 national election after having voted Nationalist in 2008 were still inclined to confirm their vote in the 2014 European election. Long electoral cycles are also consistent with infrequent alternation in government, which is a recurrent characteristic of small states (Taagepera 1999; Sikk \& Taagepera 2014). In addition, decreasing popularity through the cycle (rather than falls in the middle and recovery at the end) seems to capture better the relationship between FOE and SOE in such cases (Hix \& Marsh 2011).

\section{Conclusions}

The 2014 European election in Malta largely conformed to the SOE model. In comparison with the 2013 national election, turnout and valid votes fell; large and government parties lost votes, while small and opposition parties gained. To the degree to which it conformed to the SOE model, the election was different from that in many other European countries - especially from other southern member states, which saw their party systems shaken by the economic recession. It can safely be claimed that in Malta the 'giant is (still) sleeping' (Van der Eijk \& Franklin 2004) and that the country still finds itself in a state of 'permissive consensus' towards the EU (Lindberg \& Scheingold 1970).

Maltese voters - or, perhaps more correctly, the STV - allocated the six available seats equally between the two main Maltese parties, the Nationalists and Labour. 
Together, these parties attracted more than 90 per cent of the votes cast, with the rest shared almost equally between the third party, $\mathrm{AD}$ - which yet again failed to obtain parliamentary representation - and IE, a neo-fascist formation that delivered a surprising performance and came close to winning three per cent of the votes. The election was mostly fought on domestic issues, and was part of a longer electoral cycle in which the Nationalists have progressively lost votes to Labour. This decline began with the 2004 European elections, continued in the 2008 national elections and the 2009 European elections and culminated in the 2013 national elections that returned Labour to government after almost 25 years in opposition.

On its own, the gentler impact of the economic crisis on Malta does not explain the outcome of the election and its second-order character. On the one hand, the election produced some signs - such as the vote for IE - that Malta was in some way attuned to the broader Eurosceptic mood. On the other, we have shown that the somewhat deviant result of the 2014 European election in Malta is more accurately explained by a combination of factors. The stable political institutions of Malta's majoritarian democracy - and notably the strongly centralised government and almost perfect twoparty system - shield the system from the challenge of outsiders. The bipolarisation of the political system has been reinforced by the achievement of independence, and by the socio-cultural texture of the country as it developed in the second half of the twentieth century. Against this background, Malta's distinctive path to EU membership also contributed to the marginalisation of anti-EU political actors, removing the incentives for campaigning against Europe. Finally, the more immediate context of the election indicates that, taken together, persistent economic growth, a relatively large share of the public favouring the EU and a broad societal shift towards post-materialist values provided an unattractive basis for EU contestation.

However, this article has also shown that, though remarkably stable, the political system is not inert. Change manifested itself in less visible yet significant respects. One of these was the election of women, part of a broader change in the social mood culminating in the 2011 divorce referendum and the 2013 Civil Unions Act. The success of the extreme-right IE also surprised observers. And yet Malta elected no explicitly Eurosceptic party. This was probably the main aspect in which the Maltese vote departed most visibly from the outcome of the elections in other southern EU member countries. However, to conclude that Malta's elected MEPs would not represent Euroscepticism in the European Parliament would be misleading. Alfred Sant, a prominent figure within the main governing party, concentrated his campaign on a posture strongly critical of the EU and received by far the highest number of preferences among all candidates. He surely garnered the EU-critical, if not the Eurosceptic, vote, and the Labour Party eventually asked him to lead its delegation in the European Parliament.

The 2014 election outcome is indicative of the capacity of the two main parties to provide representation to a wide range of positions, thus neutralising the challenge of smaller parties. However, it also indicates the persistence of a considerable share of voters who are lukewarm towards the EU. The Eurobarometer time series shows that 
the EU has an overall solidly positive image among the Maltese, but it also notes a rising share of public opinion that is neutral towards the EU. As long as membership remains a positive-sum game for Malta, the main parties can manage to internalise opposition to the European project; however, while the joint operation of political institutions ad cultural-historical and contextual factors effectively shield Malta from successful anti-EU political actors, some embers smouldering beneath the ashes could be invigorated by a changing economic climate or some other unexpected event. At that point, it remains to be seen whether Malta's political institutions would be as effective at preventing those tensions from awakening the sleeping giant.

\section{Disclosure Statement}

No potential conflict of interest was reported by the authors.

\section{Notes}

1. See article by Schmitt and Teperoglou (2015).

2. Ibid.

3. $Q=\left(\frac{\text { Valid Votes }}{6 \text { seats }+1}\right)+1$

4. In 2003, 2008 and 2013 national elections the average Droop quota was 3,619, 3,729 and 3,918. Thus for example in $2013 \mathrm{AD}$, which obtained 5,506 first-count votes, was nowhere close to obtaining a full quota in at least one district to enable it to capture a seat. Theoretically, a party could have obtained close to between 40,000 and 50,000 votes without electing one seat by falling just short of the quota in all districts.

5. For example, the Nationalists won the 2008 national election with a margin of about 1,500 votes, which gave them a one-seat majority in parliament.

6. Around one-fifth of respondents did not reply or claimed not to know which party they would be voting for. This may have contributed to the mismatch between the percentages shown in the poll on voters' intentions and the actual election results.

\section{References}

Carrubba, C. \& Timpone, R.J. (2005) 'Explaining vote switching across first- and second-order elections: evidence from Europe', Comparative Political Studies, vol. 38, no. 3, pp. 260-281. doi:10.1177/0010414004272693.

Cini, M. (2000) 'The Europeanization of Malta: adaptation, identity and party politics', South European Society and Politics, vol. 5, no. 2, pp. 261-276. doi:10.1080/13608740508539611.

Cini, M. (2002) 'A divided nation: polarization and the two-party system in Malta', South European Society and Politics, vol. 7, no. 1, pp. 6-23. doi:10.1080/714004966.

Cini, M. (2003) 'Malta votes twice for Europe: the accession referendum and general election, March/ April 2003', South European Society and Politics, vol. 8, no. 3, pp. 132-146. doi:10.1080/ 13608740808539659.

Cini, M. (2004) 'Culture, institutions and campaign effects: explaining the outcome of Malta's EU accession referendum', West European Politics, vol. 27, no. 4, pp. 584-602. doi:10.1080/ 0140238042000249911.

Debono, J. (2014) 'MaltaToday survey: Labour in six-point lead', MaltaToday, 22 May, available online at http://www.maltatoday.com.mt/news/europe_2014/39279/maltatoday_survey_ labour_in_sixpoint_lead\#,VHCMk_15OVV 
Doron, G. \& Kronick, R. (1977) 'Single transferrable vote: an example of a perverse social choice function', American Journal of Political Science, vol. 21, no. 2, pp. 303-311. doi:10.2307/ 2110496.

Duverger, M. (1951) Political Parties: Their Organization and Activity in the Modern State, Wiley, New York.

Eurostat. (2015) 'Population change: demographic balance and crude rates at national level', available online at http://appsso.eurostat.ec.europa.eu/nui/show.do?dataset=demo_gind\& lang=en

Fenech, D. (2008) 'The 2008 Maltese general election: the tortoise and the hare', West European Politics, vol. 31, no. 5, pp. 1049-1054. doi:10.1080/01402380802234755.

Fenech, D. (2012) 'Divorced from political reality: the new limits of ecclesiastical power in Malta', The Round Table, vol. 101, no. 3, pp. 221-234. doi:10.1080/00358533.2012.690966.

Fenech, D. (2013) 'The 2013 Maltese general election: unplugging the blockage', West European Politics, vol. 36, no. 5, pp. 1088-1094. doi:10.1080/01402382.2013.815479.

Harwood, M. (2015) 'Adopting same-sex unions in Catholic Malta: pointing the finger at "Europe"', South European Society and Politics, vol. 20, no. 1, pp. 113-131. doi:10.1080/13608746.2014. 953350.

Hirczy, W. (1995) 'Explaining near-universal turnout: the case of Malta', European Journal of Political Research, vol. 27, no. 2, pp. 255-272. doi:10.1111/j.1475-6765.1995.tb00638.x.

Hix, S. \& Marsh, M. (2007) 'Punishment or protest? Understanding European Parliament elections', The Journal of Politics, vol. 69, no. 2, pp. 495-510. doi:10.1111/j.1468-2508.2007.00546.x.

Hix, S. \& Marsh, M. (2011) 'Second-order effects plus pan-European political swings: an analysis of European Parliament elections across time', Electoral Studies, vol. 30, no. 1, pp. 4-15. doi:10. 1016/j.electstud.2010.09.017.

Hobolt, S. B. \& Wittrock, J. (2011) 'The second-order election model revisited: an experimental test of vote choices in European parliament elections', Electoral Studies, vol. 30, no. 1, pp. 29-40. doi:10.1016/j.electstud.2010.09.020.

Katz, R. (1984) 'The single transferable vote and proportional representation', in Choosing an Electoral System: Issues and Alternatives, eds A. Lijphart \& B. Grofman, Praeger, New York.

Koepke, J. R. \& Ringe, N. (2006) 'The second-order election model in an enlarged Europe', European Union Politics, vol. 7, no. 3, pp. 321-346. doi:10.1177/1465116506066259.

Laakso, M. \& Taagepera, R. (1979) 'Effective number of parties: a measure with application to West Europe', Comparative Political Studies, vol. 12, no. 1, pp. 3-27.

Lane, J. C. (1995) 'The election of women under proportional representation: the case of Malta', Democratization, vol. 2, no. 2, pp. 140-157. doi:10.1080/13510349508403433.

Lijphart, A. (1999) Patterns of Democracy: Government Forms and Performance in 36 Countries, Yale University Press, Yale.

Lindberg, L.N. \& Scheingold, S.A. (1970) Europe's Would-Be Polity: Patterns of Change in the European Community, Prentice Hall, Englewood Cliffs.

Marsh, M. (1998) 'Testing the second-order election model after four European elections', British Journal of Political Science, vol. 28, no. 4, pp. 591-607. doi:10.1017/S000712349800026X.

Ortega Villodres, C. (2008) 'Gender and party duopoly in a small state: ballot position effects under the single transferable vote in Malta, 1947-2008', South European Society and Politics, vol. 13, no. 4, pp. 435-456. doi:10.1080/13608740902735018.

Pace, R. (2002) 'A small state and the European Union: Malta's EU accession experience', South European Society and Politics, vol. 7, no. 1, pp. 24-42. doi:10.1080/714004965.

Pace, R. (2004) 'Malta’s EU membership: chapter 1 concluded, chapter 2 just started', Mediterranean Politics, vol. 9, no. 1, pp. 114-121. doi:10.1080/13629390410001679955. 
Pace, R. (2005) 'South European integration watch: the Maltese electorate turns a new leaf? The first European Parliament election in Malta', South European Society and Politics, vol. 10, no. 1, pp. 121-136. doi:10.1080/13608740500038005.

Pace, R. (2009) 'The European Parliament election in Malta, June 6, 2009', EPERN - European Parties Elections and Referendums Network, Working Paper 27.

Pace, R. (2011) 'Malta: euroscepticism in a polarised polity', South European Society and Politics, vol. 16, no. 1, pp. 133-157. doi:10.1080/13608740903454155.

Pace, R. (2012) 'Growing secularisation in a Catholic society: the divorce referendum of 28 May 2011 in Malta', South European Society and Politics, vol. 17, no. 4, pp. 573-589. doi:10.1080/ 13608746.2012.755761.

Pace, R. \& Carammia, M. (forthcoming) 'Malta', in Les Democraties Européennes, eds J.M. de Waele, N. Brack \& J.B. Pilet, Armand Colin, Paris.

Reif, K. \& Schmitt, H. (1980) 'Nine second-order national elections - a conceptual framework for the analysis of European election results', European Journal of Political Research, vol. 8, no. 1, pp. 3-44. doi:10.1111/j.1475-6765.1980.tb00737.x.

Schmitt, H. (2005) 'The European Parliament elections of June 2004: still second-order?', West European Politics, vol. 28, no. 3, pp. 650-679. doi:10.1080/01402380500085962.

Schmitt, H. \& Teperoglou, E. (2015) 'The 2014 European Parliament elections in Southern Europe: second-order or critical elections?', South European Society and Politics, vol. 20, no. 3. doi:10. 1080/13608746.2015.1078271.

Sikk, A. \& Taagepera, R. (2014) 'How population size affects party systems and cabinet duration', Party Politics, vol. 20, no. 4, pp. 591-603. doi:10.1177/1354068811436068.

Taagepera, R. (1999) 'The number of parties as a function of heterogeneity and electoral system', Comparative Political Studies, vol. 32, no. 5, pp. 531-548. doi:10.1177/0010414099032005001.

Van der Eijk, C. \& Franklin, M.N. (2004) 'Potential for contestation on European matters at national elections in Europe', in European Integration and Political Conflict, eds G. Marks \& M.R. Steenbergen, Cambridge University Press, Cambridge, pp. 32-50.

Marcello Carammia is a senior lecturer in comparative politics at the Institute for European Studies, University of Malta. His research focuses on political institutions and agenda-setting at the comparative and EU level. His articles have appeared in journals including the Policy Studies Journal, European Union Politics and the Italian Political Science Review.

Roderick Pace is a professor of international relations and the Director of the Institute for European Studies, University of Malta, where he is also the current holder of the Jean Monnet Chair. His research focuses on relations between the EU and the Mediterranean countries, but he has also written extensively on Malta and the EU, Maltese politics, small states and theories of European integration. His work has appeared in several journals and books. He is a member of the Editorial Board of South European Society and Politics. 